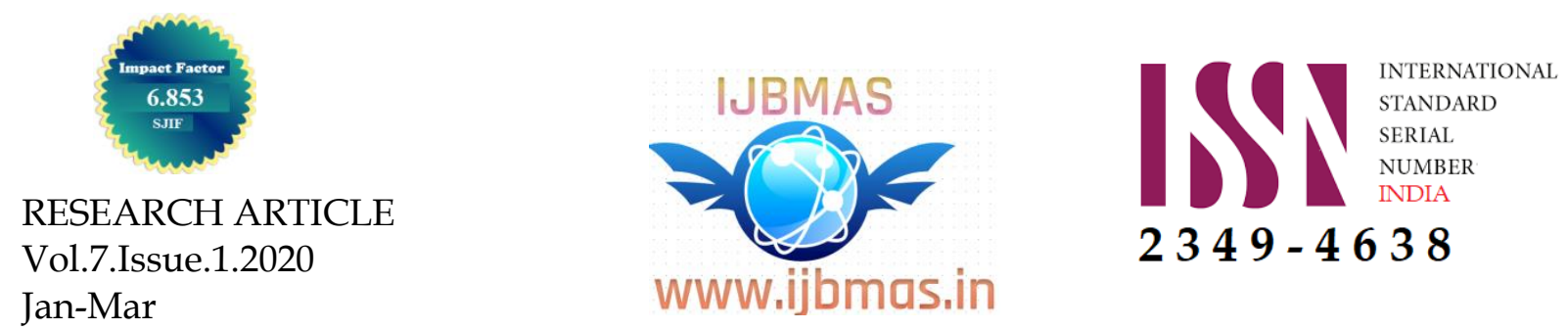

INTERNATIONAL JOURNAL OF BUSINESS, MANAGEMENT AND ALLIED SCIENCES (IJBMAS)

A Peer Reviewed and refereed Journal

\title{
BANKING SECTOR REFORMS IN INDIA
}

\author{
Dr.SK.MABUNNI', Prof.T.SREENIVAS ${ }^{2}$ \\ ${ }^{1}$ Associate Professor, Department of Management Sciences, RVR\&JC College of Engineering, \\ Guntur, Andhra Pradesh. \\ Email:mabunni.mba@gmail.com \\ 2Department of Business Management, Yogi Vemana University, Kadapa, Andhra Pradesh. \\ Emial:tallurus@gmail.com
}

DOI: $10.33329 /$ ijbmas.7.1.67

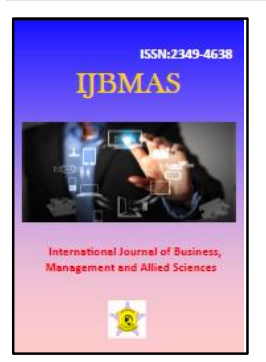

\begin{abstract}
Banking is the life blood of business, commerce and industry. In modern day context, banking sector acts as the back bone of present business. The growth and development of any country mainly depends upon its banking system. A bank is a financial institution which deals with deposits and advances and other related services. It collects money from those who want to save in the form of deposits and it lends money to those who in need of it. The Banking System in India is dominated by nationalized banks. The performance of the Indian banking system is more closely linked to the economy than perhaps that of any other sector. The main objective of this study is to present the structure of Indian banking sector and to understand various reforms of it. The task of banking system is particularly vital as one of the leading and mostly essential service sector. Indian banking system continues to deal with improvement in asset quality, implementation of sensible risk management practices and capital adequacy. The paper focuses on the impact of banking sector reforms and analysis in Indian banking system.
\end{abstract}

Keywords: Banking Industry, Reforms, Service Sector

\section{Introduction}

Banking sector reforms started with the goal to improve the overall performance of the Indian banking sector. In the context of economic liberalization and growing trend towards globalization, different banking sector reforms have been introduced in India to improve the operational efficiency and to promote the health and financial reliability of banks so that Indian banks can meet internationally accepted standards of performance. To make Indian banks, internationally competitive and encourage them to play an effective role in accelerating the process of growth reforms play a key role. The reforms in the banking sector in India intended to enhance the stability, efficiency and effectiveness of banks. It removes the operational rigidities in the credit delivery system and ensures 
allocation efficiency and achievement of social objectives. The reforms have been strengthening the measures which are aimed at reducing the vulnerability of banks in the face of fluctuations in the economic environment. These included capital adequacy, income recognition, asset classification, provisioning norms, exposure norms, enhanced levels of transparency, and disclosure standards.

\section{Objectives of the study}

1. To study the structure of banking industry, history of banking sector reforms and the various reasons behind the banking sector reforms in India.

2. To discuss the various committees and their recommendations towards the banking sector reforms.

3. To identify the challenges of post reform and to suggest the possible remedial measures.

\section{Review of Literature:}

Shivamagi ${ }^{1}$ (2000), in his article discussed the reforms required in rural banking. He found that although rural banking in India has made tremendous quantitative progress, its quality is a different matter. He further stated that to be suitable for and effective in India, a rural banking system should be able to operative at the village level, advance a tailor made package of credit with a consumption component and closely monitor its disbursement to a large number of farmers in varied villages and provide technical guidance and marketing support. He summarised that the policy makers should give thrust to nurturing of special skills in institutions, a positive management attitude and a culture conducive to healthy rural banking. Shete 2 (2003) presented in his study those priority sector advances of banks during the post reform period. He argued that the priority sector advances of banks have come down substantially during the post reform era, despite the expansion of scope/areas of priority sector definition. Arora and Kaur $^{3}$ (2006) stated that banking sector in India has given a positive and encouraging response to the financial sector reforms. Entry of new private banks and foreign banks in India has shaken up public sector banks to face tough competition. Sanjeev Kumar ${ }^{4}$, (2010), in his Thesis observed the performance measurement system in Indian Banking Sector in CAMELS framework and explained that CAMEL framework is an important performance measurement system based on different ratios used to find out ranking of the banks.

\section{History of Banking Sector Reforms in India}

Pre Independence: Modern banking in India started with the establishment of the General Bank of India in 1786. In 1806, the East India Company established the primary Presidency Bank in Kolkata.

Another two more banks were established in 1840 and 1843 named Bank of Bombay and Bank of Madras. Reserve Bank of India (RBI) was established on April 1, 1935, with the enactment 50 of the Reserve Bank of India Act, 1934. The theme of establishing the Reserve Bank, as stated in the preamble to the RBI Act, was to "regulate the issue of bank notes and the keeping of reserves with a view of securing monetary stability in India".

Post-Independence: Even after independence, the banks were mainly urban-oriented and were beyond the reach of the rural population. A large section of the rural population still had to look upon the money lenders as their resort for credit. That's why the government decided to nationalize all the major banks in India. The first Nationalization took place in 1969 and the second in 1985.

\footnotetext{
1 Shivamagi H. B., "Reforms in Rural banking - Need for Bolder Approach", Economic and Political Weekly, May 13, 2000, pp. 1714-18.

2 Shete N.B, "Banking Sector Reforms and Priority Sector Credit", Management and Accounting Research, Vol. 3. No. 1, July- September 2003, pp. 1-20

3 Arora, Sangeeta and Kaur, Shubpreet (2006), "Financial Performance of Indian Banking Sector in Post Reforms Era", The Indian Journal of Commerce, Vol. 59, No. 1, Jan-March.

4 Sanjeev Kumar(2010): Performance of the Indian Banking Sector: Impact of Reform.
} 
Reasons behind the Banking Reforms in India: The Indian economy witnessed a series of difficulties like uncertain political situation, persistent fiscal imbalance, double-digit inflation, the balance of payments crisis, etc. Growth of real GDP decelerated to some extent because of lower industrial growth and partly because of the slowdown in agriculture. The industries were affected because of lower government investment; non-availability of inputs due to import compress, recession prevailed in the industrial economy due to the downfall of demand in the markets of Kuwait and Iraq in the wake of Gulf crisis, and the collapse of the erstwhile Soviet Union.

\section{Structure of Indian Banking Industry}

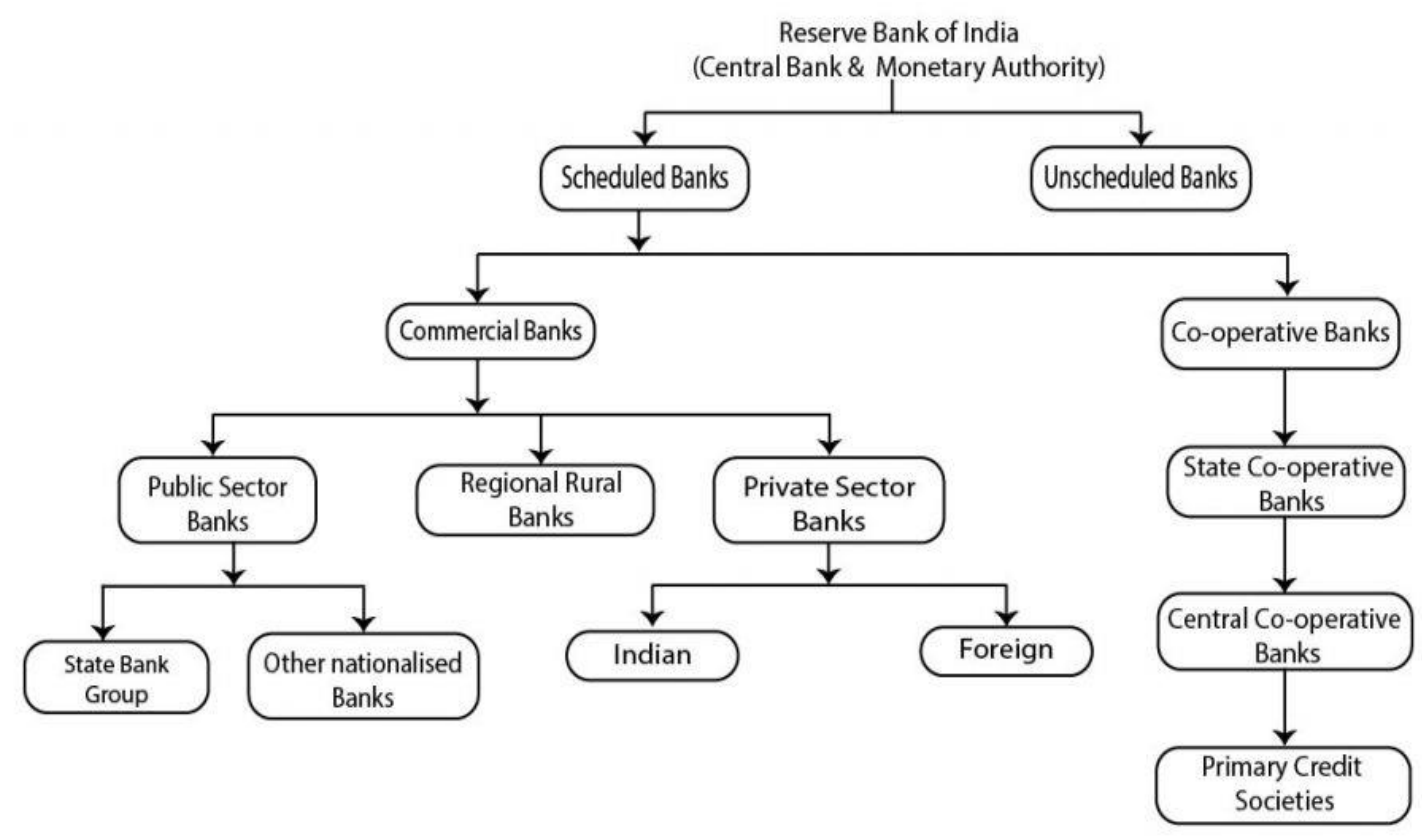

Figure 1 Structure of Banking Industry in India

Reforms in the banking sector were introduced on the basis of the recommendations of different committees:

1. The first Narasimhan Committee (1991)

2. The Verma Committee (1996)

3. The Khan Committee (1997)

4. The Second Narasimhan Committee (1998).

\section{The First Phase of Reforms:}

The banking sector reforms are directed toward improving the policy framework, financial health and the institutional framework:

\section{- Change in Policy Framework}

Improvement in policy framework has been undertaken by decreasing the Cash Reserve Ratio (CRR) to the initial standard and phasing out Statutory Liquidity Ratio (SLR), deregulation of interest rates, widening the scope of lending to priority sectors and by linking the lending rates to the size of advances.

\section{- Improving Financial Health}

Attempts to improve the financial accuracy of the banking sector have been made by prescribing prudential norms. Moreover, steps have been taken to reduce the proportion of Non-Performing Assets (NPAs). 
- Improvements of Institutional Framework:

(i) Recapitalisation,

(ii) Creating a competitive environment, and

(iii) Strengthening the supervisory system.

\section{Second Phase Reforms:}

The first phase of the bank sector reforms is completed. The second generation reforms which are in progress concentrate on strengthening the very establishment of the banking system in three ways: by reforming the structure of the banking industry, technological up gradation, and human resource development.

\section{Prudential Regulation}

There are two types of banking regulations - economic and prudential. In the pre-reform era the Reserve Bank of India regulated banks by imposing constraints on interest rates, narrowing entry norms and directed lending to ensure judicious end use of bank credit. However, such economic regulation of banks troubled their productivity and efficiency. Hence, the RBI switched over to prudential regulation which calls for imposing minimum limit on the capital level(s) of banks. The objective is to maintain the wealth of banks in particular and to ensure the reliability of the financial system in general. It allows much greater scope for the free play of market forces than what is permitted by economic regulations alone. On the basis of recommendations of the Committee on Banking Sector Reforms, April 1998 (the second Narasimhan Committee) the RBI issued prudential norms. The main purpose of setting such norms was to make sure of financial safety, soundness and solvency of banks. These norms are directed toward ensuring that banks carry on their operations as prudent entities, are free from undue risk-taking, and do not violate banking regulations in pursuit of profit.

\section{The main focus of reforms was in three areas:}

(i) NPAs

(ii) Capital adequacy

(iii) Diversification of operations

(i) Non-Performing Assets (NPAs): One severe problem faced by the public sector banks in the 1990s was a high proportion of NPAs. An NPA is an asset from which income is overdue for more than six months. According to the second Narasimhan Committee report (1998), "No other single indicator reflects the quality of assets and their impact on banks' viability than the NPA figures in relation to advances." The gross NPAs of scheduled commercial banks (SCBs) increased over the period March 31, 1998 to March 31, 2002 from Rs 51,815 crores to Rs 70,924 crores. Gross NPA of public sector banks (PSBs) were also correspondingly higher. However, the share of PSBs in total NPAs declined from $90 \%$ to $82 \%$ during the period (1998-2002). Furthermore, there was a turn down in the ratio of gross NPAs and net NPAs, measured as percentage of advances as well as assets. These ratios represent the quality of banks assets and are thus taken as measures of reliability of the banking system. Gross and net NPAs as a proportion of gross advances and total assets of SCBs declined substantially during this period. However, the ratio of gross and net NPAs as a proportion of gross advances and of total assets increased significantly for new private sector banks from 2001-02 due to the merger of strong banks with weak banks. But the origin of increase in NPAs is the increasing the percentage of bad debt. In case of some banks, net NPAs even exceeded their net worth. This means that such banks had negative net worth.

(ii) Capital Adequacy Ratio: Banking sector reforms were initiated by implementing prudential norms consisting of Capital Adequacy Ratio (CAR). The core of such reforms has been the expanding of prudential norms to the internationally accepted standards. In 1988 the Basel Committee for international banking supervision made an attempt worldwide to reduce the number of bank failures 
by tying a bank's CAR to the riskiness of the loans it makes. Throughout the world, commercial banks are under the legal commitment to maintain minimum capital funds for safety purpose. The reason is that a bank's capital base is significantly important for its long-term variability. It also acts as a shock absorber in the medium term since it gives the power to absorb shocks and thus avoid the risk of bankruptcy.

(iii) Diversification in Bank Operations: During the period of economic liberalisation Public Sector Banks have diversified their activities significantly. They have moved in new areas such as mutual funds, merchant banking, venture capital funding and other para banking activities such as leasing (lease financing), hire-purchase, factoring, forfaiting and so on. The main objective has been to gain profits by deriving maximum economies of scale and scope, expanding customer base and providing various types of banking services under one umbrella (both directly as also through subsidiaries). Many banks such as the SBI have become a one-stop financial services centre.

\section{Post reform challenges of Indian banking sector}

Indian Commercial Banks have made good progress in all performance parameters including annual deposits and credit growth, profitability and declining trend in NPAs, with overall capital adequacy reaching 16 percent as on 31 March 2012. Comfortable levels of public deposit in the Banking Sector ensured most Banks to have a comfortable liquidity profile.

Banks have benefited from good economic growth during the last decade, implementation of SARFAESI Act, setting up of Credit Information Bureaus, leveraging latest technology and infrastructure, updating of risk management processes etc. have all contributed towards the overall improvement. However, some adverse have also been faced by the Indian Banking Sector like slowdown in economy during 2008-09, tight liquidity position, wage hikes in the Banking System, higher provisioning and capital requirements etc. Gross NPAs are on the rise since 2010-11 due to weakening of credit profiles of borrowers, because of following factors, among others:

- Slowdown in demand / economy

- Increasing cost pressures resulting in lower operating profits of corporate India

- Higher interest rates which are not favorable

- capital market to raise the equity

Indian Commercial Banks are facing at present, several challenges including deregulation of savings rates, tighter monetary policy, increased stressed assets, especially in sectors like aviation, micro finance, state utilities, infrastructure sector, implementation of BASEL III requirements etc.

\section{The other challenges include}

With changing global economic situations, demand for speedy, secure and effective service delivery from beneficiaries, information and communication revolution, big bang long gestation infrastructure projects, the problems of banking system undergone drastic changes

- Bad loan

- Cyber Threats

- Twin balance sheet

- Bank scam

- The new Bankruptcy Code

- Non Performing Assets

- Requirements of Reserve Ratio

- Increasing Competition and funding sources 
With the growing penetration of computers and smart phones, and increasing access to the internet, Indians are taking digital channels for their banking purposes for which cybercrime is becoming a major threat. The RBI classifies bank fraud as transactions involving any cheating, negligence, misappropriation of funds, or forged documents.

The Public sector banks are hampered with the high Non Performing Assets while some of the business houses are also under stress due to sluggish global demand. This is called Twin Balance Sheet Syndrome Problem. This leads to incomplete transmission of the monitory policy, unwillingness of banks to lend credit on account of rising NPAs affecting credit growth in turn economic activity.

\section{Suggested Remedies to be followed by Indian banking sector to overcome the challenges}

- The level of competition should be gradually increased within the banking sector while simultaneously introducing international top practices in prudential regulation, supervision and implementation.

- Special emphasis should be placed on building up the risk management capabilities of Indian banks while measures were originated to ensure flexibility, operational autonomy and competition in the banking sector.

- Vigorous steps and measures must be taken to improve the institutional arrangements including the legal framework and technological system.

- The monitoring system should be revamped in view of the crucial role of supervision in the creation of an efficient banking system.

- Increase the emphasis on corporate governance.

- Consolidation of banks could be achieved through merger or share purchase.

- Improve credit appraisal capability of banks especially project appraisal, post sanction monitoring and its implementation.

- Mandatory forensic audit pre sanction of loans for specific class of borrowers to prevent diversion of funds.

- Reinforcement of Development Financial Institutions for financing of long term projects including infrastructure projects

- Developing a customer-centric business practice.

- Smart banking embracing Artificial Intelligence \& Cognitive technologies.

\section{Conclusion}

To line up with the changing environment, each country makes its own economic policy and India is not the exception. New economic policy (Liberalization, Privatization and Globalization) is responsible to change the economic environment in India also. To meet these dynamic changes, economic structure in the form of finance, money and capital market, is changing time-to-time and banking is also one of them. Before the economic reforms, there were so many deficiencies and rigidities in the Indian economy. The Indian financial sector was on the crossroads. To remove the severe crises of 1991 and to improve the performance of the Indian commercial banks, first banking sector reforms were introduced in 1991 and after their success government gave much importance to the second phase of the reforms in 1998. After the gap of six years, now it had become imperative to modify some of the old reforms and introduced some new reforms in the global age. Suggested third phase of reforms will help to strengthen the ongoing economic reforms by identifying different challenges and to be include the necessary remedies to overcome. 


\section{References}

[1]. Ahluwalia, Montek S. (2002), “ Economic reforms in India since 1991: Has Gradualism worked?”, Journal of economic Prespectives, 16(3), pp. 67-88.

[2]. Arora, Sangeeta and Kaur, Shubpreet. (2006), “Financial Performance of Indian Banking Sector in Post Reforms Era", The Indian Journal of Commerce, Vol. 9, No. 1, Jan-March.

[3]. Shete N.B. (2003), "Banking Sector Reforms and Priority Sector Credit", Management and Accounting Research, Vol. 3. No. 1, July- September 2003, pp. 1-20.

[4]. Singh Tejmani N and Das Niranjan Chandra.(2002), "Reforms in the Banking Sector - An Overview", Banking Finance, June 2002, pp. 7-8.

[5]. Janaki Ramudu P, Durga Rao. (2006), "A Fundamental analysis of Indian Banking Industry", The ICFAIJournal of Bank Management.

[6]. Sanjeev Kumar.(2010), "Performance of the Indian Banking Sector: Impact of Reform"

[7]. Shivamagi H. B. (2000), "Reforms in Rural banking - Need for Bolder Approach", Economic and Political Weekly, May 13, 2000, pp. 1714-18.

[8]. Singh, Gupta and Shandilya. (2010), "Banking and financial sector reforms in India", Serials Publication, New Delhi, India. 